\title{
The Effect of Shoreline Recreational Angling Activities on Aquatic and Riparian Habitat Within an Urban Environment: Implications for Conservation and Management
}

\author{
Amanda C. O'Toole · Kyle C. Hanson • \\ Steven J. Cooke
}

Received: 1 June 2008/Accepted: 2 April 2009/Published online: 19 May 2009

(C) Springer Science+Business Media, LLC 2009

\begin{abstract}
There is growing concern that recreational shoreline angling activity may negatively impact littoral and riparian habitats independent of any direct or indirect influences of fish harvest or fishing mortality through mechanisms such as disturbance (e.g., trampling, erosion) and pollution (e.g., littering). We sampled a suite of aquatic and terrestrial variables (i.e., water quality, aquatic and terrestrial macrophytes, soil compaction, anthropogenic refuse) at 14 high shoreline angling-activity sites (identified by way of interviews with conservation officers and angling clubs) within an urban area (Ottawa, Canada). For each high angling-activity site, a nearby corresponding low angling-activity site was sampled for comparison. We found that the percentage of barren area and soil compaction were greater in areas of high angling activity compared with areas that experienced relatively low angling activity. In addition, terrestrial and aquatic macrophyte density, height, and diversity were lower at high angling-activity sites. Angling- and non-angling-related litter was present in large quantities at each of the high angling-activity sites, and comparatively little litter was found at low anglingactivity sites. Collectively, these findings indicate that shoreline angling does alter the riparian environment, contributing to pollution and environmental degradation in areas of high angling intensity. With growing interest in providing urban angling opportunities and in response to
\end{abstract}

\footnotetext{
A. C. O'Toole · S. J. Cooke $(\bowtie)$

Institute of Environmental Science, Carleton University, Ottawa, ON K1S-5B6, Canada

e-mail: steven_cooke@carleton.ca

A. C. O'Toole $\cdot$ K. C. Hanson · S. J. Cooke

Fish Ecology and Conservation Physiology Laboratory, Department of Biology, Carleton University, Ottawa,

ON K1S-5B6, Canada
}

increasing interest in developing protected areas and parks, a better understanding of the ecologic impacts of shoreline angling is necessary to address multiuser conflicts, to develop angler outreach and educational materials, and to optimize management of angling effort to maintain ecologic integrity of riparian and aquatic ecosystems.

Keywords Shoreline angling - Conservation - Riparian . Ecosystem health - Soil compaction · Angling litter . Macrophyte

\section{Introduction}

Globally, there is increasing evidence that recreational angling is contributing to decreased aquatic ecosystem health (Cooke and Cowx 2006). Although recreational fishing may be considered a relatively low-impact activity in terms of environmental degradation, the potential impacts of angling are often underestimated (Post and others 2002; Cooke and Cowx 2004, 2006; Lewin and others 2006). Participation rates vary extensively throughout the world (Arlinghaus and Cooke 2008); however, overall global estimates suggest that as many as 727 million anglers participate in recreational fishing annually (Cooke and Cowx 2004). In Canada alone, $>3.2$ million people engage in angling activities each year (Department of Fisheries and Oceans Canada 2007). In the United States, this number is closer to 34 million (United States Fish and Wildlife Service 2001). With the bulk of human populations focused in urban centres, participation in urban recreational fishing activities is often high, and these recreational fisheries provide important social and economic benefits because many cities offer convenient access to shoreline fishing sites where anglers of all ages and ability levels may participate in 
recreational fishing activities (Fedler and Ditton 1994; Schramm and Edwards 1994). Because of the potential cumulative effects associated with recreational angling, there is cause for concern in terms of conservation and maintenance of aquatic and adjacent terrestrial (e.g., shorelines, coasts, riparian areas) ecosystems.

To date, much work on the effects of recreational angling has focused on interactions between the angler and the individual fish that are targeted or captured either intentionally or as by-catch, including those that are harvested as well as those caught and released. More than 200 studies have focused on the injury, stress, and mortality associated with angling and releasing fish relative to factors such as gear type, environmental conditions, and angler behaviour (reviewed in Arlinghaus and others 2007). Clearly, harvest can result in fishery declines because this is increasingly being observed in coastal and inland recreational fisheries (Post and others 2002; Coleman and others 2004). However, many of these fish are released (global estimates suggest release rates of 60\% [Cooke and Cowx 2004]); thus, unintentional mortality may result. In addition, fishery-induced selectivity may influence size and age structure of fish populations, genetic variability, evolutionary changes, and ecosystem trophic cascades (Lewin and others 2006).

However, like the commercial fishing sector (Dayton and others 2005), broader environmental impacts are associated with recreational fishing in freshwater systems that extend beyond impacts on individual fish or fish populations as a direct result of harvest or fishing mortality. For example, anthropogenic debris along shorelines and in adjacent water bodies have a negative impact on the local environment (Cryer and others 1987; Radomski and others 2006). Loss of fishing gear (e.g., line, lures, hooks, lead weights) along shorelines can affect both the substrate in which it is deposited as well as wildlife present in the area (Forbes 1986; Cryer and others 1987; Lewin and others 2006; Radomski and others 2006). Lead has a slow dissolution rate and a high stability in sediment, leading to ingestion by waterfowl, which subsequently may suffer the effects of lead poisoning (Cryer and others 1987; Scheuhammer and others 2003). In addition, waterfowl have also been shown to become entangled in discarded fishing line (Cryer and others 1987; Franson and others 2003).

Areas that experience high fishing effort may also be subjected to considerable shoreline changes because of general human activity, which can lead to a cascade of deleterious changes in both the terrestrial and aquatic environments. Increased foot traffic into angling access points could potentially lead to removal of vegetation (Cole 1987; Marion and Cole 1996; Müller and others 2003), loss of plant diversity (Cole 1987; Ros and others 2004), soil compaction (Marion and Cole 1996; Roovers and others
2004; Andrés-Abellán and others 2005), and erosion, factors that have rarely been studied in the context of recreational fishing (Cooke and Cowx 2006; Lewin and others 2006) but are known in terms of hiking and camping impacts (reviewed in Sun and Walsh 1998). In turn, because riparian vegetation is important in providing overhead cover and shade for fish and also in anchoring soil, riparian disturbance may lead to increased shoreline erosion as well as decreased habitat complexity (Delong and Brusven 1991; Schiemer and others 1995; Schindler and Scheuerell 2002). Soil compaction increases bulk density and decreases soil porosity (Lei 2004), further contributing to erosion processes, surface runoff into nearby watersheds, and water-quality degradation (Kozlowski 1999). Subsequently, poor water quality can have detrimental effects on the health, distribution, and abundance of aquatic flora and fauna (Miner and Stein 1996). Highly turbid water can decrease sunlight penetration into the water column, restricting submergent plant growth, obstructing fish gills (Sutherland and Meyer 2008), and affecting predator-prey interactions (Miner and Stein 1996). Dissolved oxygen is a major limiting factor for fish, with low levels having significant physiologic effects (Kramer 1987; Kruk 2007). With the removal of shoreline vegetation at angling access points, shade in nearshore areas may be decreased, thus increasing water temperatures while locally decreasing dissolved oxygen levels. The ultimate impacts of recreational angling activity on the abiotic environment may lead to short- and long-term impacts on fish populations and aquatic ecosystems because of changes in the structure and condition of these systems (Lewin and others 2006) as well as to the broader interconnected terrestrial-aquatic system.

In marine systems, protected areas and zoning are being used to regulate human use and activities. However, similar efforts have not been widely used in freshwater systems (Suski and Cooke 2007), although some aquatic areas are protected by being contained within terrestrial protected areas. At present, however, there is insufficient information on the ecologic and environmental consequences of shoreline angling to optimize the management of angling effort to maintain the ecologic integrity of riparian and aquatic ecosystems. With growing emphasis on creating recreational fishing opportunities in or near urban centres, there is a need for information on the potential environmental consequences of recreational fishing to ensure that the ecologic integrity of riparian systems is maintained. Hence, the objective of this study was to evaluate links between shoreline angling and changes in aquatic and shoreline systems to determine the potential ecologic impacts of shoreline angling in and near a major urban centre in North America. We predicted that areas experiencing high frequencies of angling activity might be 
subject to increased levels of ecologic degradation compared with areas not exposed to the same degree of anthropogenic disturbance. We expected to see decreases in water quality, evidence of anthropogenic waste, decreased riparian vegetative cover (resulting in greater barren area and soil compaction), and lower fish diversity in such areas.

\section{Methods}

\section{Study Site}

Between July 16 and 27, 2007, we sampled a set of 14 shoreline angling-activity sites and 14 corresponding low angling-activity sites (28 sites in total) in the Ottawa, Ontario, and Gatineau, Quebec, regions of Canada. The greater Ottawa-Gatineau metropolitan area has a population $>1.3$ million people, and $20 \%$ of urban land use in the region is devoted to parks and green space (City of Ottawa Census Data 2006). The Ottawa-Gatineau region has a number of warm-water lakes and large rivers, most of which are dominated by fish from the family Centrarchidae. Centrarchids (including smallmouth bass [Micropterus dolomieu], largemouth bass [Micropterus salmoides], pumpkinseed [Lepomis gibbosus], bluegill Lepomis macrochirus], and black crappie [Pomoxis nigromaculatus]) as well as other members of the local fish fauna (including common carp [Cyprinus carpio], channel catfish [Ictalurus punctatus], northern pike [Esox lucius], muskellunge Esox masquinongy], and walleye [Sander vitreus]) can be easily angled from shore. Local municipalities as well as the provincial fish and wildlife agency (i.e., the Ontario Ministry of Natural Resources) have developed maps and fishing guides specifically intended to facilitate shoreline angling in and around this urban area. Because the goal of the study was to evaluate the impacts of shoreline fishing activity, it was necessary to identify locales where this activity was common. It is also important to recognize that virtually all shorelines are somewhat accessible to anglers; however, there is clearly a range of fishing activity across locations.

Initially, a local conservation officer and local anglers were consulted to gain information about locations of popular shoreline angling locations. Subsequently, each site was visited to determine suitability for inclusion in the study (i.e., to evaluate whether there were signs of angler use). Sites with recent evidence of shoreline angling (barren and compacted soil, trampled vegetation, presence of fishing-related debris, etc.) were designated as treatment sites and eventually sampled. Sites with artificially hardened shorelines, docks, and cement wall structures were avoided because of the impossibility of measuring some variables (e.g., soil compaction, vegetation, etc.) at these locales. Furthermore, site selection was focused at locations where there was minimal evidence of other human use (e.g., dog walking, canoe launching), which would confound the study. However, it is important to note that for both high angling- and low angling-activity sites, it is possible that other human use occurs. For comparison, a low angling-activity site (control) was selected $25 \mathrm{~m}$ away from each high angling-activity site (direction along the shoreline in relation to the high angling-activity site was determined randomly). The low angling-activity sites were relatively undisturbed compared with the associated high angling-activity sites, and no anglers were noted at these locations. In total, 14 pairs of high angling activity-sites and associated control sites were sampled (7 located on the Rideau River, 6 on the Ottawa River, and 1 on Dow's Lake). The majority of the sites sampled were lotic systems; however, water velocities at these sites were low enough to be considered comparable with the more lentic sites sampled.

\section{Data Collection}

At each site, both aquatic and terrestrial sampling was conducted to detect differences in five suites of variables corresponding to water quality, soil compaction, discarded litter, macrophyte density and abundance, and fish community. In high angling-activity areas, onshore sampling was centred at the area that would most likely be where an angler would stand while fishing. To quantify the close range and immediate effects of angling activity, such as soil compaction and discarded litter, a $0.25-\mathrm{m}^{2}$ quadrat was placed at the location where an angler would most likely position his or her feet while fishing (the "angler stand"). A soil sample was taken from the centre of the angler stand using a $100-\mathrm{cm}^{3}$ soil corer. Each soil sample was preserved in an airtight bag, later dried in an oven for $42 \mathrm{~h}$ at $85^{\circ} \mathrm{C}$, and then weighed to the closest tenth of a gram to determine bulk density $\left(\mathrm{cm}^{3} / \mathrm{g}\right)$. In addition, we noted the percentage of barren area as well as the number of species and height of the four tallest plants of onshore plants found within the quadrat. A second, larger onshore $6-\mathrm{m}^{2}$ quadrat was set up to quantify the effects of angling within the area in which a typical fishing rod would reach. Percentage of barren area, number of plant species, and the height of the four tallest plants were measured within the 6- $\mathrm{m}^{2}$ quadrat. We collected litter (both angling-specific [e.g., lure packaging, worm containers] and non-angling-specific [e.g., pop cans, cigarette butts]) within the $6-\mathrm{m}^{2}$ quadrat as well as the $0.25-\mathrm{m}^{2}$ quadrat. The weight of each piece of litter was determined to the closest tenth of a gram, and the lengths of fishing line fragments were measured to the nearest centimetre. Low angling-activity sites were sampled in the same manner, although the $0.25-\mathrm{m}^{2}$ quadrat 
was randomly placed rather than centred on an area of angler activity.

Aquatic sampling was conducted at three distances $(0,5$, and $10 \mathrm{~m}$ from the water's edge) perpendicular to the shore, in line with the designated angler standing position. At each sampling distance, a $0.25-\mathrm{m}^{2}$ quadrat was placed on the bottom to measure variables at those immediate locations. First, a water sample was obtained from each site to determine turbidity values (in nephelometric turbidity units [NTU]) using a turbidity meter (LaMotte model 2020, Chesterton, MD). Water temperature $\left({ }^{\circ} \mathrm{C}\right)$ and dissolved oxygen $(\mathrm{mg} / \mathrm{L})$ readings were taken at each of the three distances from shore at a depth of $30 \mathrm{~cm}$ below the water's surface using a handheld meter (YSI Model 85 Handheld Oxygen, Conductivity, Salinity, and Temperature System, Yellow Springs, $\mathrm{OH}$ ). Within the $0.25-\mathrm{m}^{2}$ quadrat (at each site), a snorkeler measured depth, distance to the closest cover (from the centre of the quadrat), and type of cover. The types of cover included in the study were any in-water structure that fish could use for foraging activities and predator avoidance (e.g., aquatic macrophyte beds, boulders, large woody debris). Within the quadrat, macrophyte density, height of the four tallest individual macrophytes, and number of species (species richness) were quantified. Angling- and non-angling-specific litter was collected and processed in the same manner as previously described at each of the three $0.25-\mathrm{m}^{2}$ quadrats. Finally, shortly after sampling (so as to mitigate disturbances associated with sampling), a fish community survey of number of species and number of individuals was performed by the snorkeler (Dolloff and others 1996) within a $10 \times 10$-m quadrat extending out into the water, centred on the onshore angler standing position. The survey was completed by swimming the quadrat at a slow, regulated speed in 10-m long sections to cover the entire $100 \mathrm{~m}^{2}$ area.

\section{Data Analysis}

Because there was nonnormal distribution of some components of the data set, a series of nonparametric Wilcoxon signed-rank tests were performed to compare differences between onshore and aquatic variables at high angling- and low angling-activity sites (Zar 1999). Fish diversity was assessed using the Shannon Wiener Index (H'), and differences were compared using Wilcoxon signed-rank test (Zar 1999). All analyses were conducted using the statistical software program JMP v. 7.0 (SAS Institute, Raleigh, $\mathrm{NC}$ ), and results were assessed for significance at $\alpha=0.05$. Because there were multiple comparisons, we applied Bonferroni corrections to all variables, and both corrected and uncorrected alpha values are presented (see Tables 1 through 4). All values are presented as means \pm SEs unless otherwise noted.

\section{Results}

Aquatic Variables

Water-quality metrics (i.e., dissolved oxygen, turbidity, water temperature) were generally similar between high angling- and low angling-activity sites at 0,5 , and $10 \mathrm{~m}$ from shore (Table 1). Low angling-activity sites were characterized by increased numbers of aquatic macrophyte species, higher macrophyte densities (\% cover), and greater macrophyte height $(\mathrm{cm})$ directly along the shoreline $(0 \mathrm{~m}$ from shore) compared with high angling-activity sites (number of species: $W=-18.0, P=0.008$; density: $W=-21.0, P=0.012$; height: $W=-20.50, P=0.012$; Table 1). We did not detect differences in aquatic macrophyte diversity, density, or height between high anglingand low angling-activity sites at 5 and $10 \mathrm{~m}$ from shore (Table 1).

\section{Terrestrial Variables}

Differences between high angling- and low angling-activity sites were noted in all terrestrial variables measured within both the $6-\mathrm{m}^{2}$ and $0.25-\mathrm{m}^{2}$ quadrats (Table 2). The percentage of barren area was much higher in the high angling-activity sites compared with low angling-activity sites $\left(0.25-\mathrm{m}^{2}\right.$ quadrat: $W=45.5, \quad P=0.0002 ; 6-\mathrm{m}^{2}$ quadrat: $W=45.5, P=0.0002)$. High angling-activity sites had nearly $100 \%$ barren area in the $0.25-\mathrm{m}^{2}$ quadrat areas (Fig. 1a), and 6- $\mathrm{m}^{2}$ quadrats in the high anglingactivity areas had nearly four times the amount of barren area as the low angling-activity sites (Table 2). Plant height $(\mathrm{mm})$ was higher in both the $0.25-\mathrm{m}^{2}$ and the $6-\mathrm{m}^{2}$ quadrats at low angling-activity sites $\left(0.25-\mathrm{m}^{2}\right.$ quadrat: $W=-44.0, \quad P=0.0007 ; \quad 6-\mathrm{m}^{2}$ quadrat: $W=-44.5$, $P=0.0005$; Table 2 and Fig. 1b). Low angling-activity sites typically contained more plant species $(W=-45.5$, $P=0.0002$ ) within the $0.25-\mathrm{m}^{2}$ quadrats than did paired high angling-activity sites (Table 2 and Fig. 2a). Low angling-activity sites also had a higher percentage of natural shoreline vegetation compared with high anglingactivity sites $(W=-39.0, \quad P=0.0005$; Table 2 and Fig. 2b). Last, soil compaction was greater in high anglingthan in low angling-activity sites as evidenced by differences in soil bulk density $(W=15.0, P=0.0391$; Table 2 and Fig. 2c).

\section{Litter}

The number of pieces of angling-related litter as well as the number of pieces of non-angling-specific litter was much higher at high angling-activity sites (angling-related litter: $W=44.5, P=0.0005$; non-angling-related litter: $W=45.5$, 
Table 1 Comparison of aquatic variables between low angling- and high angling-activity sites in the Ottawa-Gatineau region ${ }^{\mathrm{a}}$

\begin{tabular}{|c|c|c|c|c|c|c|c|c|}
\hline Variable & $\begin{array}{l}\text { Distance from shore } \\
\text { (m) }\end{array}$ & $N$ & $\begin{array}{l}\text { LAA } \\
\text { (median) }\end{array}$ & $\begin{array}{l}\text { HAA } \\
\text { (median) }\end{array}$ & $\begin{array}{l}\mathrm{LAA} \\
(\text { mean } \pm \mathrm{SE})\end{array}$ & $\begin{array}{l}\text { HAA } \\
(\text { mean } \pm \text { SE) }\end{array}$ & $W$ & $P$ \\
\hline \multirow[t]{3}{*}{ Turbidity (NTU) } & 0 & 14 & 3.4 & 3.2 & $4.37 \pm 1.10$ & $3.94 \pm 1.14$ & -1.50 & 0.951 \\
\hline & 5 & 14 & 2.1 & 2.2 & $3.55 \pm 1.28$ & $3.16 \pm 0.95$ & -18.50 & 0.261 \\
\hline & 10 & 14 & 2.2 & 2.0 & $3.30 \pm 1.10$ & $3.10 \pm 0.98$ & -12.50 & 0.463 \\
\hline \multirow[t]{3}{*}{ Dissolved oxygen (mg/L) } & 0 & 14 & 8.1 & 7.7 & $8.30 \pm 0.37$ & $8.07 \pm 0.38$ & -30.50 & 0.056 \\
\hline & 5 & 14 & 8.3 & 8.1 & $8.28 \pm 0.39$ & $8.20 \pm 0.37$ & -0.50 & 0.988 \\
\hline & 10 & 14 & 8.3 & 8.0 & $8.47 \pm 0.43$ & $8.25 \pm 0.37$ & -17.50 & 0.289 \\
\hline \multirow[t]{3}{*}{ Temperature $\left({ }^{\circ} \mathrm{C}\right)$} & 0 & 14 & 23.9 & 24 & $24.37 \pm 0.53$ & $24.53 \pm 0.48$ & 23.00 & 0.115 \\
\hline & 5 & 14 & 24 & 23.7 & $24.39 \pm 0.35$ & $24.21 \pm 0.45$ & 7.00 & 0.649 \\
\hline & 10 & 14 & 24.1 & 23.7 & $22.74 \pm 1.57$ & $23.94 \pm 0.38$ & -16.00 & 0.167 \\
\hline \multirow[t]{3}{*}{ Depth (cm) } & 0 & 14 & 20 & 20 & $19.54 \pm 2.29$ & $20.82 \pm 2.04$ & 2.00 & 0.915 \\
\hline & 5 & 14 & 110 & 106.5 & $106.57 \pm 2.98$ & $114.31 \pm 7.53$ & -1.00 & 0.964 \\
\hline & 10 & 14 & 140 & 132.5 & $147.14 \pm 18.43$ & $161.15 \pm 21.01$ & -2.00 & 0.916 \\
\hline \multirow[t]{3}{*}{ Distance to Cover $(\mathrm{cm})$} & 0 & 14 & 50 & 80 & $64.64 \pm 20.60$ & $117.62 \pm 28.71$ & 27.50 & 0.087 \\
\hline & 5 & 14 & 40 & 30 & $63.14 \pm 18.40$ & $88.46 \pm 37.19$ & -11.50 & 0.501 \\
\hline & 10 & 14 & 50 & 40 & $78.07 \pm 28.09$ & $62.08 \pm 20.65$ & -6.00 & 0.698 \\
\hline \multirow[t]{3}{*}{ No. macrophyte spp. } & 0 & 14 & 1 & 0 & $1.29 \pm 0.34$ & $0.43 \pm 0.29$ & -18.00 & 0.008 \\
\hline & 5 & 14 & 1 & 1 & $1.36 \pm 0.39$ & $0.43 \pm 0.29$ & -2.50 & 0.805 \\
\hline & 10 & 14 & 1 & 1 & $1.29 \pm 0.34$ & $0.79 \pm 0.24$ & -10.50 & 0.285 \\
\hline \multirow{3}{*}{$\begin{array}{l}\text { Macrophyte density (\% } \\
\text { cover) }\end{array}$} & 0 & 14 & 20 & 0 & $26.43 \pm 7.53$ & $1.86 \pm 1.44$ & -21.00 & 0.012 \\
\hline & 5 & 14 & 12.5 & 15 & $13.21 \pm 3.80$ & $26.36 \pm 7.95$ & 19.50 & 0.182 \\
\hline & 10 & 14 & 8.5 & 11.5 & $22.29 \pm 8.18$ & $17.92 \pm 5.19$ & -7.00 & 0.563 \\
\hline \multirow[t]{3}{*}{ Macrophyte height (cm) } & 0 & 14 & 98.1 & 0 & $223.80 \pm 76.38$ & $27.50 \pm 17.61$ & -20.50 & 0.012 \\
\hline & 5 & 14 & 313.5 & 210.5 & $235.11 \pm 56.86$ & $228.25 \pm 63.56$ & 6.00 & 0.677 \\
\hline & 10 & 14 & 279.5 & 224 & $234.29 \pm 60.69$ & $228.25 \pm 63.56$ & -0.50 & 1.00 \\
\hline
\end{tabular}

$H A A$ high angling-activity site, LAA low angling-activity site

${ }^{a}$ Analyses were conducted using Wilcoxon signed-rank test. Italicized statistical output indicate significant results $(\alpha=0.05)$. Bonferroni corrections were applied, and significant values were evaluated at $\alpha=0.006$

Table 2 Comparison of terrestrial variables between low angling- and high angling-activity sites in the Ottawa-Gatineau region ${ }^{\mathrm{a}}$

\begin{tabular}{lrllrrrr}
\hline Variable & $N$ & LAA (median) & HAA (median) & LAA (mean \pm SE) & HAA (mean \pm SE) & $W$ & $P$ \\
\hline Barren area $/ 0.25 \mathrm{~m}^{2}(\%)$ & 14 & 25 & 99.9 & $38.21 \pm 10.35$ & $95.50 \pm 2.19$ & 45.50 & $\boldsymbol{0 . 0 0 0 2}$ \\
Barren area $/ 6 \mathrm{~m}^{2}(\%)$ & 14 & 10 & 80 & $19.29 \pm 4.50$ & $76.00 \pm 5.94$ & 45.50 & $\mathbf{0 . 0 0 0 2}$ \\
No. of plant species $/ 0.25 \mathrm{~m}^{2}$ & 14 & 3.5 & 1 & $4.50 \pm 1.40$ & $2.07 \pm 1.13$ & -45.50 & $\mathbf{0 . 0 0 0 2}$ \\
Plant height $/ 0.25 \mathrm{~m}^{2}(\mathrm{~mm})$ & 14 & 170.4 & 1 & $214.10 \pm 46.77$ & $19.54 \pm 9.24$ & -44.00 & $\mathbf{0 . 0 0 0 7}$ \\
Plant height $/ 6 \mathrm{~m}^{2}(\mathrm{~mm})$ & 14 & 770.2 & 300 & $923.75 \pm 109.66$ & $330.98 \pm 54.76$ & -44.50 & $\boldsymbol{0 . 0 0 0 5}$ \\
Natural shoreline vegetation $(\%)$ & 14 & 98 & 12.5 & $79.71 \pm 8.94$ & $18.29 \pm 5.86$ & -39.00 & $\boldsymbol{0 . 0 0 0 5}$ \\
Bulk density $(\mathrm{g} / \mathrm{cm})$ & 8 & 1.12 & 1.43 & $1.02 \pm 0.09$ & $1.42 \pm 0.09$ & 15.00 & 0.0391 \\
\hline
\end{tabular}

HAA high angling-activity site, LAA low angling-activity site

${ }^{a}$ Analyses were conducted using Wilcoxon signed-rank test. Italicized statistical output indicates significant results $(\alpha=0.05)$. Bonferroni corrections were applied, and significant values $(\alpha=0.007)$ are presented in bold

$P=0.0002$; Table 3 and Fig. 3a). Correspondingly, weight (g) of both angling-related and non-angling-related litter was also higher at high angling-activity sites (weight of angling-related litter: $W=47.5, P=0.0012$; weight of non-angling-related litter: $W=47.5, P=0.0012$; Table 3 and Fig. 3b). More discarded fishing line was found at high angling-activity sites. Indeed, the length of line was 900 times longer at high angling- than low angling-activity sites $(W=45.5, P=0.0002)$. The average length of fishing line segments found at the 14 high angling-activity sites was $906 \pm 335 \mathrm{~cm}$, and a total of $127 \mathrm{~m}$ of fishing line was found across all 14 locations. This compares with the 
Fig. 1 Comparison of shoreline metrics for $0.25-\mathrm{m}^{2}$ and $6-\mathrm{m}^{2}$ quadrats for high angling- and low angling-activity sites using Wilcoxon signed rank tests $(\alpha=0.007)$. a Barren area $(\%)$. b Average plant height $(\mathrm{cm})$
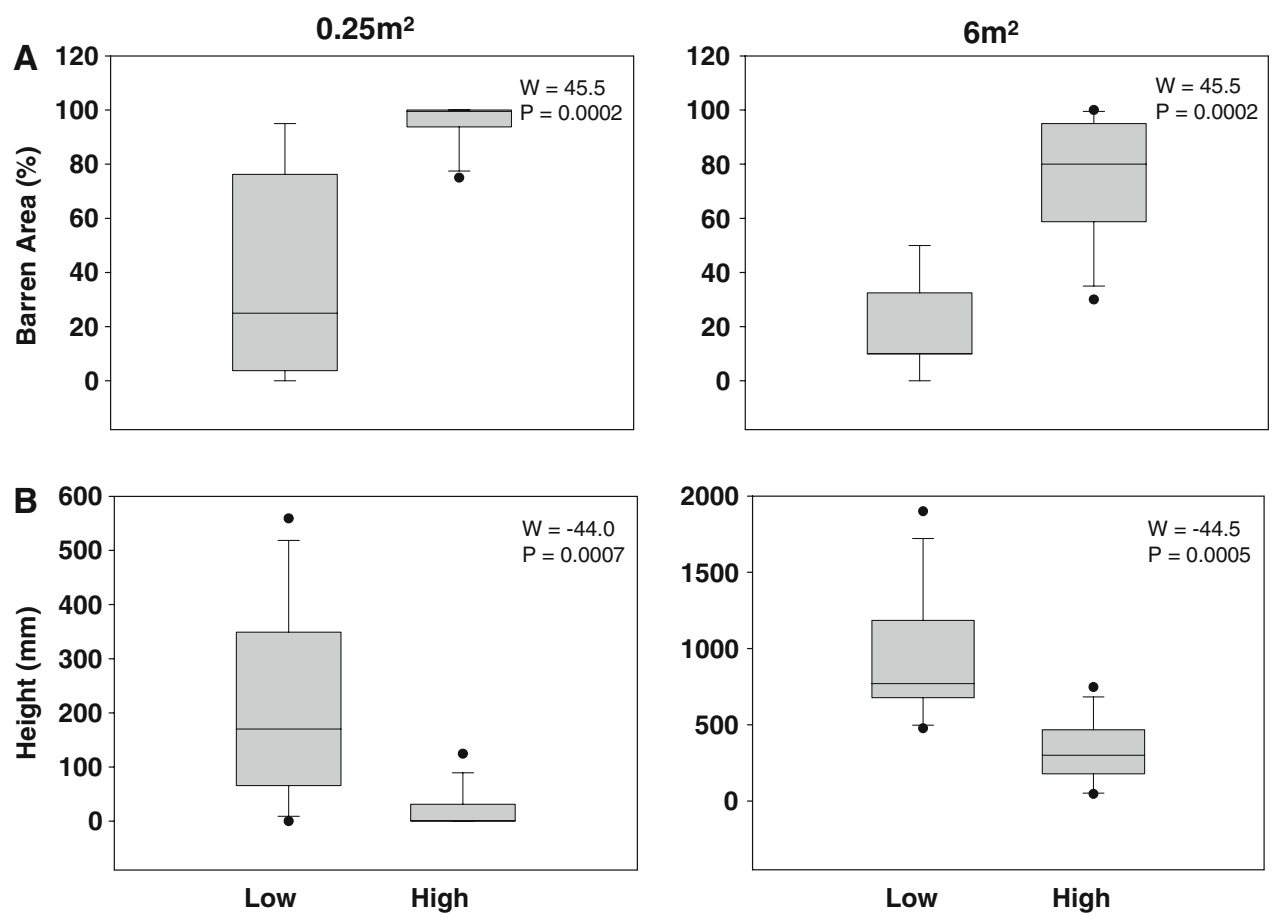

Angling Activity Sites

complete lack of fishing line found at any of the low angling-activity sites. The average number lead pieces found at high angling-activity sites was $0.86 \pm 0.39$ pieces, and the average weight of lead pieces collected at high angling-activity sites was $3.5 \pm 1.85 \mathrm{~g}$. We did not find any lead fishing gear at low angling-activity sites.

\section{Fish Species Metrics}

The most common fish species we encountered at each of the sites were mainly members of the centrarchid family (smallmouth bass, bluegill, and pumpkinseed), brown bullhead (Ameirurus nebulosus), yellow perch (Perca flavescens), and various cyprinids. Fish species richness and abundance were not different between sites of high and low angling activity (Table 4).

\section{Discussion}

Many urbanized regions offer opportunities for recreational fishing, with convenient access to shoreline angling sites suitable for anglers of varying age and experience (Schramm and Edwards 1994). Our selection of sampling sites was based on several criteria, including evidence of trampling, soil compaction, decreased vegetation cover, and, most importantly, presence of angling-related waste. In addition, a conservation officer (who visits areas of highangling intensity frequently to optimize enforcement and outreach efforts) and local anglers (involved in the leadership of local angling clubs) were consulted before the study, and their recommendations were used to select the locations of the study sites. However, our low anglingactivity sites were always chosen randomly (25 m either upstream or downstream from high-angling sites) and served as relevant controls. It is important to note that although some sites also displayed evidence of other recreational use (canoe launching, dog walking), fishing activity was always apparent. We recognized that we were intentionally selecting high angling-activity sites and then identified the exact locations where we believed anglers stood to fish. Indeed, we often saw anglers at these sites before, during, or after the study. Conversely, we never saw anglers at the low angling-activity sites. As such, we believe that our site selection and sampling procedures were valid.

The percentage of barren area in high angling-activity sites was considerably greater than at low angling-activity sites, which was likely caused by the increased foot traffic into angling access points. Increased foot traffic typically restricts plant growth (Cole 1987; Sun and Walsh 1998), decreases plant diversity (Ros and others 2004) and average plant height, and leads to increased soil compaction (Manning 1979; Marion and Cole 1996; Andrés-Abellán and others 2005). In turn, decreased plant growth was correlated with decreased percentage of natural shoreline at sites of high angling activity (Table 2). Human disturbance caused by foot traffic was shown to affect soil compaction 

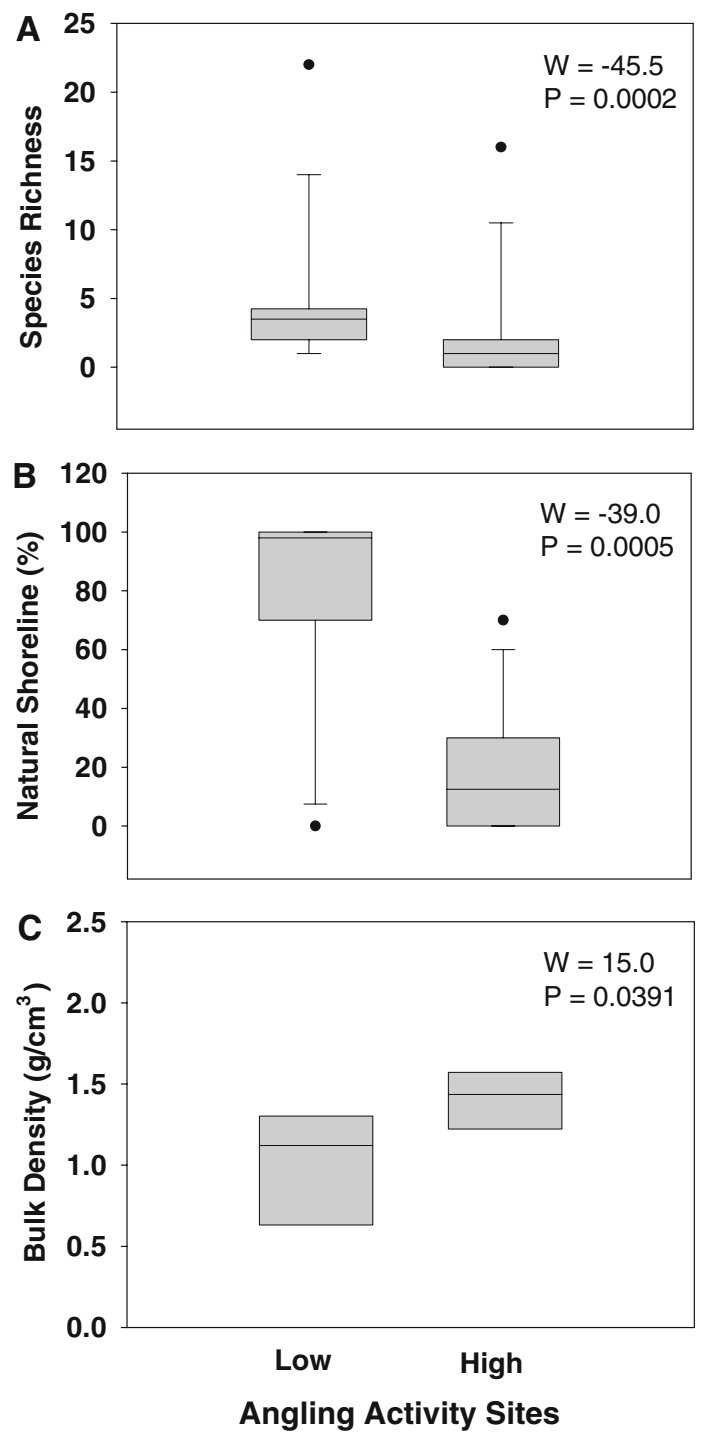

Fig. 2 Comparison of shoreline metrics for high angling- and low angling-activity sites using Wilcoxon signed rank tests. a Species richness $(\alpha=0.007)$. b Natural shoreline (\%; $\alpha=0.007)$. c Soil bulk density $\left(\mathrm{g} / \mathrm{cm}^{3} ; \alpha=0.05\right)$ in a number of studies (Marion and Cole 1996; AndrésAbellán and others 2005; Amrein and others 2005). Andrés-Abellán and others (2005) found that soil bulk density ranged from 1.43 to $1.48 \mathrm{~g} / \mathrm{cm}^{3}$ and that barren area was on average $61 \%$ in campsites with high levels of foot traffic. These values are similar to our findings that average bulk density values were $1.42 \mathrm{~g} / \mathrm{cm}^{3}$ at high angling-activity sites. Other studies have also shown that species richness and density of ground vegetation is decreased in areas that experience high recreational use (Marion and Cole 1996; Ros and others 2004; Amrein and others 2005).

Aquatic macrophyte diversity, density, and height were greater at low angling-activity sites, but only in the areas near the shore. It is unclear whether anglers were the direct reason for the decrease in aquatic macrophyte abundance and size at high angling-activity sites or if anglers consciously choose these sites because of the lack of macrophytes at that location. Slipke and others (1998) performed a creel survey in which they found that angler preference for abundance of aquatic macrophytes was dependent on the fish species targeted. Anglers targeting largemouth bass preferred a greater abundance of aquatic macrophytes, and anglers targeting other species preferred less macrophyte coverage at their fishing sites (Slipke and others 1998). In addition, anglers may be actively removing aquatic macrophytes while fishing (e.g., by unintentionally snagging macrophytes) because desiccated aquatic macrophytes were often observed at angling sites where they had been removed from fishing gear and discarded onshore. A decrease in macrophyte growth and diversity in nearshore high angling-activity sites may also be attributed to anglers wading into the water from the bank and trampling aquatic vegetation.

Water quality did not vary between high angling- and low angling-activity sites (Table 1). One would expect that water quality would be degraded in areas exposed to high angling activity because other variables in these areas

Table 3 Comparison of angling- and non-angling-related litter found at low angling- and high angling-activity sites in the Ottawa-Gatineau region $^{\mathrm{a}}$

\begin{tabular}{|c|c|c|c|c|c|c|c|}
\hline Variable & $N$ & $\begin{array}{l}\text { LAA } \\
\text { (median) }\end{array}$ & $\begin{array}{l}\text { HAA } \\
\text { (median) }\end{array}$ & $\begin{array}{l}\text { LAA } \\
(\text { mean } \pm \mathrm{SE})\end{array}$ & $\begin{array}{l}\text { HAA } \\
(\text { median } \pm \text { SE) }\end{array}$ & $W$ & $P$ \\
\hline Pieces of angling-related litter & 14 & 0 & 9.5 & $2.67 \pm 0.41$ & $13.14 \pm 3.26$ & 44.50 & 0.0005 \\
\hline Pieces of non-angling-related litter & 14 & 0 & 6.5 & $5.00 \pm 1.51$ & $10.79 \pm 2.73$ & 45.50 & 0.0002 \\
\hline Weight of angling-related litter (g) & 14 & 0 & 6.03 & $0.22 \pm 0.21$ & $10.66 \pm 3.53$ & 47.50 & 0.0012 \\
\hline Weight of non-angling-related litter $(\mathrm{g})$ & 14 & 0 & 11.58 & $11.90 \pm 7.03$ & $25.06 \pm 7.55$ & 47.50 & 0.0012 \\
\hline Length of fishing line (cm) & 14 & 0 & 540.9 & $0.00 \pm 0.00$ & $906 \pm 335.7$ & 45.5 & 0.0002 \\
\hline No. of lead pieces & 14 & 0 & 0 & $0.00 \pm 0.00$ & $0.86 \pm 0.39$ & 7.50 & 0.0625 \\
\hline Weight of lead pieces ( $\mathrm{g}$ ) & 14 & 0 & 0 & $0.00 \pm 0.00$ & $3.5 \pm 1.85$ & 7.50 & 0.0625 \\
\hline
\end{tabular}

HAA high angling-activity site, LAA low angling-activity site

a Analyses were conducted using Wilcoxon signed-rank test. Italicized statistical output indicate significant results $(\alpha=0.05)$. Bonferroni corrections were applied, and significant values $(\alpha=0.013)$ are presented in bold 
Fig. 3 Comparison of anglingwith non-angling-related litter for high angling- and low angling-activity sites using Wilcoxon signed rank tests ( $\alpha=0.007$ and $\alpha=0.05$, respectively). a Number of pieces of litter found within the 6- $\mathrm{m}^{2}$ quadrat. b Average weight (g) of litter found within the 6$\mathrm{m}^{2}$ quadrat
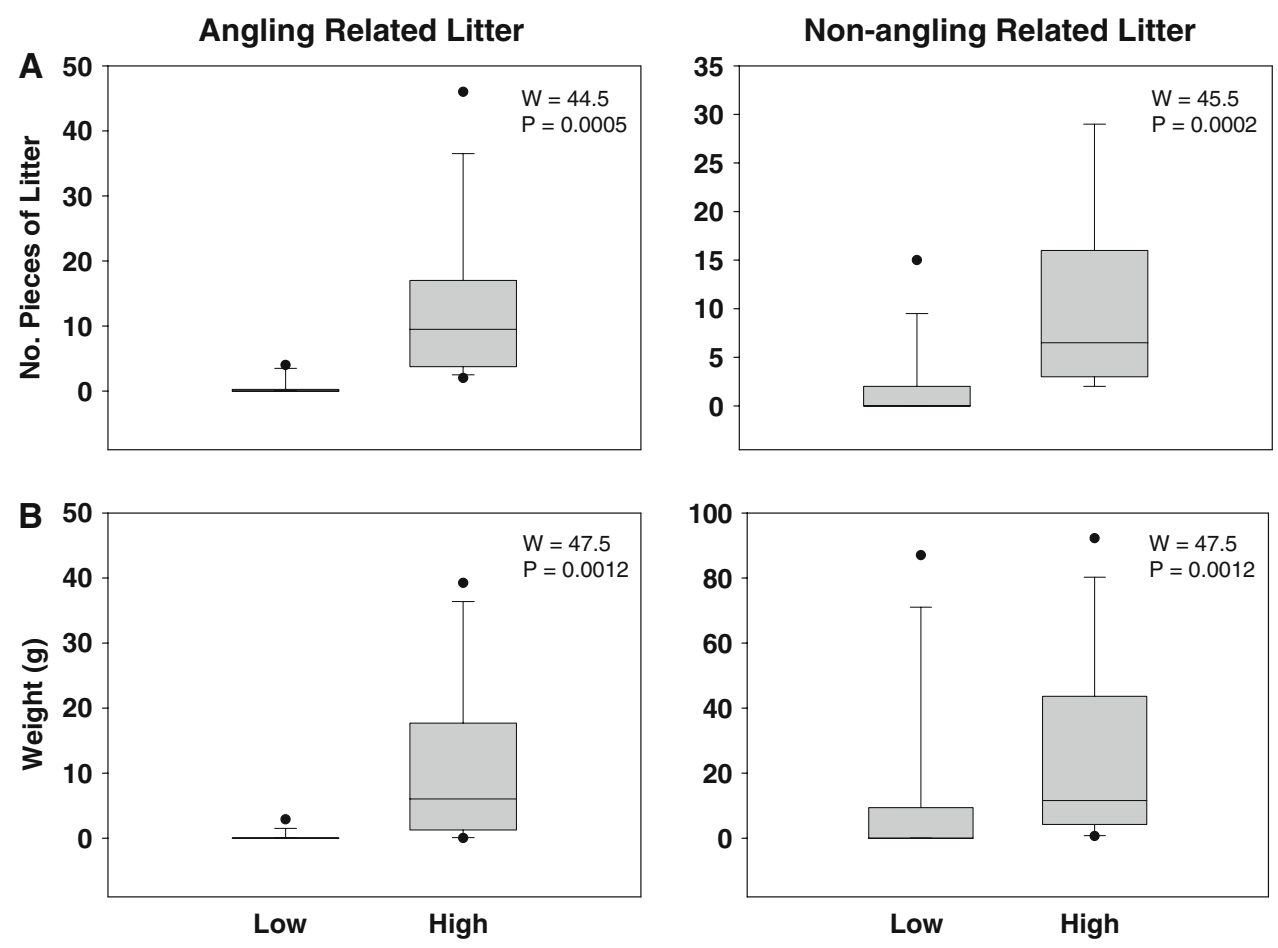

Angling Activity Sites

Table 4 Comparison of fish species diversity and number of individuals found at low angling- and high angling-activity sites in the OttawaGatineau region $^{\mathrm{a}}$

\begin{tabular}{llccrrrr}
\hline Variable & $N$ & LAA (median & HAA (median) & LAA (mean \pm SE) & HAA (mean \pm SE) & $W$ & $P$ \\
\hline Fish-species richness & 14 & 2.5 & 3 & $2.5 \pm 0.44$ & $3.0 \pm 0.62$ & 8.00 & 0.266 \\
Total fish abundance & 14 & 12 & 12.5 & $20.29 \pm 6.42$ & $22.64 \pm 7.77$ & 9.00 & 0.449
\end{tabular}

HAA high angling-activity site, LAA low angling-activity site

${ }^{a}$ Analyses were conducted using Wilcoxon signed-rank test $(\alpha=0.05)$. Bonferroni corrections were applied, and significant values were evaluated at $\alpha=0.03$

indicated ecologic disturbance (e.g., presence of litter, decreased plant cover, soil compaction). Water temperature may be affected by the extent of riparian vegetation, channel geometry, and aquatic macrophytes (LeBlanc and others 1996; King and Warburton 2007). It could be reasonable to expect that decreased shoreline vegetation as well as decreased aquatic macrophyte growth in high angling-activity areas would lead to locally increased water temperatures and therefore lower dissolved oxygen levels, especially in areas of slow-moving water. In nearshore areas of high angling activity, aquatic macrophyte growth was less than in nearshore areas of low angling activity. Because the presence of aquatic macrophytes is also associated with increased water clarity (Scheffer 1999), it could be expected that turbidity would be greater at high angling-activity sites. However, the similarities in waterquality metrics between high angling- and low anglingactivity sites may simply be related to the majority of the sites being located on riverine systems (albeit with reasonably low velocities) and because paired sites were only separated by $25 \mathrm{~m}$. Nonetheless, we focused on microscale differences, including areas right at the waterland interface, where we anticipated that effects would be detectable if they were present. In general, onshore areas seemed to experience greater disturbance from shorelineangling activities than in-water zones. Metrics such as turbidity might be expected to vary more so between sites during or after rainfall when precipitation would mobilize silt in areas where there is decreased vegetation, particularly given that the soil was compacted so water infiltration would be decreased (Luke and others 2007).

Overall, the amount of both angling- and non-anglingrelated litter was greater at high angling-activity sites. The presence of litter was apparent at each site that we visited because it was one of the defining criteria for our site selection. Although the most dominant type of anglingrelated litter was monofilament fishing line, discarded fishing gear packaging (e.g., worm containers, lure 
packaging) made up $12 \%$ of the total number of pieces of discarded angling related litter. Several local tackle shops in Ottawa provide a refund for returning used Styrofoam worm containers in an effort to decrease littering; however, clearly more education is needed. To mitigate these issues, there may also be merit in selling tackle in bulk form without packaging as an additional means of decreasing litter potential. We found an average of $905 \mathrm{~cm}$ monofilament line at high angling-activity sites. Not only is discarded fishing line aesthetically unpleasing, it also has the potential to harm wildlife. Franson and others (2003) found that 235 individuals of 8 species of waterbirds sampled (both live birds and carcasses) across 25 states during 5 years had fishing line entangled around their bodies, were embedded with hooks, or had ingested nonlead fishing litter. Presence of these materials was most apparent in waterbird species with large samples sizes $(>50)$ of brown pelicans (Pelecanus occidentalis), double-crested cormorants (Phalacrocorax auritus), and common loons (Gavia immer). Cryer and others (1987) estimated that $\leq 13.7 \mathrm{~m}$ of fishing line was lost per angler, and Forbes (1986) found that the average length of line discarded around a small, coarse fishery lake to be $56 \mathrm{~cm}$. Lead deposition can also pose a hazard to wildlife, especially to birds that ingest small stones and grit to aid digestion (Scheuhammer and others 2003). Lead poisoning in birds may result in lethal and sublethal effects, including decreased body weight, reproductive stress, and anemia (Scheuhammer and Norris 1995; Kendall and others 1996). Franson and others (2003) also found that $3.5 \%$ of common loons and $2.7 \%$ of brown pelicans had ingested lead fishing weights. Although we did not find a difference in lead fishing tackle between our high angling- and low angling-activity sites, lead pieces were found at most of the high angling-activity sites. The amount of lead found during our study was considerably less compared with previous European studies in high angling-activity areas, such as that by Cryer and others (1987), who reported up to 298 lead sinkers $/ \mathrm{m}^{2}$, and by Forbes (1986), who found the average and total weight of lead pieces to be $0.81 \mathrm{~g}$ and $33.5 \mathrm{~kg}$, respectively.

Our results also showed a lack of difference in fish community metrics (species richness and abundance) between high angling- and low angling-activity sites. We also did not find a difference between the distances to cover between high angling- and low angling-activity sites. Foraging activities and predator avoidance are influenced by habitat complexity (Snickars and others 2004; StuartSmith and others 2007). Troutman and others (2007) found that aquatic macrophyte complexity was associated with greater fish diversity and density. We had expected to see decreases in fish community structure in high anglingactivity areas as a result of decreased aquatic macrophyte growth and riparian cover (Tables 1,2). We also predicted that poor water quality would have an impact on fish community health. High turbidity can obstruct gills and interfere with predator-prey interactions (Miner and Stein 1996; Sutherland and Meyer 2008), whereas low levels of dissolved oxygen and sudden temperature changes can degrade physiologic condition as well as influence behaviour and habitat selection (Fry 1971; Kramer 1987). Because we did not see a change in water quality and aquatic macrophyte growth in areas farther than $1 \mathrm{~m}$ from shore, it is not surprising that the fish community was similar between high angling- and low angling-activity sites.

\section{Management and Conservation Implications}

To mitigate the potential deleterious effects of shoreline angling, regulators must adopt a comprehensive approach that seeks to change angler attitudes and behaviour as well as encourage compliance with local regulations. There may also be a need to revise existing regulations or enact new policy to regulate angling effort. Angler education and outreach are key components to decreasing many deleterious effects on the environment because changes in angler behaviour, especially with regard to discarded fishing equipment or other litter, are relatively straightforward solutions. Publication of educational material directed at anglers of all ages and experience levels must be made easily available. Information in this material should outline the potential for ecologic degradation because of shoreline angling as well as potential steps to mitigate the effects of a single individual. Similarly, regulators should encourage responsible angling behaviour through a few simple steps. Although the majority of the sites sampled were within close proximity to parks and recreational areas (walking and bicycle paths, parking lots), trash bins were not always within close range. A simple recommendation for litter reduction would be for the placement of bins at popular shoreline angling locations along with posted notices reminding users of the potentially harmful effects of discarding angling and non-angling waste. In addition, efforts to decrease packaging associated with fishing gear or providing incentives (e.g., deposits on Styrofoam worm containers) to return or recycle angling-related packaging would be worthwhile. It is important to note that there is also a trade-off between the broad-ranging social benefits of shoreline fishing and some of the ecologic impacts incurred by angling. Shoreline angling, especially in urban areas, provides people with a link to green space and a connection with the natural environment, valuable relaxation time, and time spent with friends and families that may be otherwise impossible in highly developed areas (Fedler and Ditton 1994; Schramm and others 2003). As such, it must be recognized that there is intrinsic value in activities 
so that shoreline angling must be preserved while minimizing potential environmental impacts.

Mitigating environmental impacts may take the form of actions such as either formalizing high angling-activity areas (and perhaps build engineered structures such as docks or fishing platforms) or restricting angling activity along natural shorelines that are still relatively undisturbed. By protecting low-use areas, fish communities will likely benefit because the same species and abundance are found at high angling-activity sites where they are subject to greater fishing pressure. If a restorative approach is taken, the timescale for ecologic recovery for most high anglingactivity sites is unknown. Further assessments must be completed before these areas can be effectively re-established. Furthermore, there is insufficient information on the ecologic and environmental consequences of shoreline angling to optimize effectively the management of angling effort to maintain ecologic integrity of riparian and aquatic ecosystems. Further research could include experimental designs involving the use of time-lapse cameras to evaluate actual user intensities at high-activity sites (i.e., angler use vs. other recreational activities, such as canoe launching or dog walking). The work presented here is intended to contribute to the deficiency in knowledge of ecologic and environmental effects of shoreline angling. We hoped that it will stimulate more research on this topic.

Acknowledgments The authors thank Vivian Nguyen and Tobias Rapp for assistance with field data collection. We also thank Hedrik Wachelka, Grant Hopkins, and Lee Willard for advice and recommendations concerning the selection of sampling sites. We thank the Ontario Ministry of Natural Resources and Parks Canada for kindly providing research permits. This research activity was supported by the Canada Foundation for Innovation, the Ontario Research Fund, the Ontario Ministry of Research and Innovation (through an Early Researcher Award to S. J. C.), and Carleton University. This work was awarded the Rideau Valley Conservation Authority "Best Poster Award" (to A. O.). Naomi Cappuccino and members of the Fish Ecology and Conservation Physiology Laboratory kindly provided input on earlier drafts of the manuscript.

\section{References}

Amrein D, Rusterholz HP, Baur B (2005) Disturbance of suburban Fagus forests by recreational activities: effects on soil characteristics, above-ground vegetation and seed bank. Applied Vegetation Science 8:175-182

Andrés-Abellán M, Del Álamo JB, Landete-Castillejos T, LópezSerrano FR, García-Morote FA, Del Cerro-Barja A (2005) Impacts of visitors on soil and vegetation of the recreational area "Nacimiento del Rio Mundo" (Castilla-La Mancha, Spain). Environmental Monitoring and Assessment 101:55-67

Arlinghaus R, Cooke SJ (2008) Recreational fisheries: socio-economic importance, conservation issues, and management challenges. In: Dickson B, Hutton JM, Adams WM (ed) Recreational hunting, conservation, and rural livelihoods: science and practice. Blackwell Science, Oxford, UK, pp 39-58
Arlinghaus R, Cooke SJ, Lyman J, Policansky D, Schwab A, Suski C et al (2007) Understanding the complexity of catch-and-release in recreational fishing: an integrative synthesis of global knowledge from historical, ethical, social, and biological perspectives. Reviews in Fisheries Science 15:75-167

City of Ottawa (2006) Ottawa Counts. City of Ottawa Statistics. Ottawa Ontario, Canada. Available at: http://www.ottawa.ca/ city_services/statistics/counts/index_en.shtml. Accessed 9 January 2008

Cole DN (1987) Effects of three seasons of experimental trampling on five montane forest communities and a grassland in western Montana, USA. Biological Conservation 40:219-244

Coleman F, Figueira WF, Ueland JS, Crowder LB (2004) The impact of United States recreational fisheries on marine fish populations. Science 305:1958-1960

Cooke SJ, Cowx IG (2004) The role of recreational fishing in global fish crises. BioScience 54:857-859

Cooke SJ, Cowx IG (2006) Contrasting recreational and commercial fishing: searching for common issues to promote unified conservation of fisheries resources and aquatic environments. Biological Conservation 128:93-108

Cryer MJ, Corbett JJ, Winterbotham MD (1987) The deposition of hazardous litter by anglers at coastal and inland fisheries in South Wales. Journal of Environmental Management 25:125135

Dayton PK, Simon SF, Agardy MT, Hofman RJ (2005) Environmental effects of marine fishing. Aquatic Conservation: Marine and Freshwater Ecosystems 5:205-232

Delong MD, Brusven MA (1991) Classification and spatial mapping of riparian habitat with applications toward management of streams impacted by nonpoint source pollution. Environmental Management 15:565-571

Department of Fisheries and Oceans, Canada (2007) Report on the 2005 Survey of Recreational Fisheries in Canada. Department of Fisheries and Oceans, Ottawa, Canada

Dolloff A, Kershner J, Thurow R (1996) Underwater observation. In: Murphy BR, Willis DW (eds) Fisheries techniques, vol 2. American Fisheries Society, Bethesda, MD

Fedler AJ, Ditton RB (1994) Understanding angler motivations in fisheries management. Fisheries 19:6-13

Forbes IJ (1986) The quantity of lead shot, nylon fishing line and other litter discarded at a coarse fishing lake. Biological Conservation 38:21-34

Franson JC, Hansen SP, Creekmore TE, Brand CJ, Evers DC, Duerr AE et al (2003) Lead fishing weights and other fishing tackle in selected waterbirds. Waterbirds 26:345-352

Fry FE (1971) The effect of environmental factors on the physiology of fish. In: Hoar WS, Randall DJ (eds) Fish physiology, environmental relations and behaviour, vol 6. Academic Press, New York, NY, pp 1-98

Kendall RJ, Lacher TE, Bunck C, Daniel B, Driver C, Grue CE et al (1996) An ecological risk assessment of lead shot exposure in non-waterfowl avian species: upland game birds and raptors. Environmental Toxicology and Chemistry 15:4-20

King S, Warburton K (2007) The environmental preferences of three species of Australian freshwater fish in relation to the effects of riparian degradation. Environmental Biology of Fishes 78: 307-316

Kozlowski TT (1999) Soil compaction and growth of woody plants. Scandinavian Journal of Forest Research 14:596-619

Kramer DL (1987) Dissolved oxygen and fish behavior. Environmental Biology of Fishes 18:81-92

Kruk A (2007) Role of habitat degradation in determining fish distribution and abundance along the lowland Warta River, Poland. Journal of Applied Ichthyology 23:9-18 
LeBlanc RT, Brown RD, FitzGibbon JE (1996) Modelling the effects of land use change on the water temperature in unregulated urban streams. Journal of Environmental Management 49:445469

Lei SA (2004) Soil compaction from human trampling, biking, and off-road motor vehicle activity in a blackbrush (Coleogyne ramosissima) shrubland. Western North American Naturalist 64:25-130

Lewin WC, Arlinghaus R, Mehner T (2006) Documented and potential biological impacts of recreational fishing: insights for management and conservation. Reviews in Fisheries Science 14:305-367

Luke SH, Luckai NJ, Burke JM, Prepas EE (2007) Riparian areas in the Canadian boreal forest and linkages with water quality in streams. Environmental Reviews 15:79-97

Manning RE (1979) Impacts of recreation on riparian soils and vegetation. Water Resources Bulletin 15:30-43

Marion JL, Cole DN (1996) Spatial and temporal variation in soil and vegetation impacts on campsites. Ecological Applications 6: $520-530$

Miner JG, Stein RA (1996) Detection of predators and habitat choice by small bluegills: effects of turbidity and alternative prey. Transactions of the American Fisheries Society 125:97-103

Müller Z, Jakab T, Toth A, Devai G, Szallassy N, Kiss B et al (2003) Effect of sports fisherman activities on dragonfly assemblages on a Hungarian river floodplain. Biodiversity and Conservation 12:167-179

Post JR, Sullivan M, Cox S, Lester NP, Walters CJ, Parkinson EA et al (2002) Canada's recreational fisheries: the invisible collapse? Fisheries 27:6-17

Radomski P, Heinrich T, Jones TS, Rivers P, Talmage P (2006) Estimates of tackle loss for five Minnesota walleye fisheries. North American Journal of Fisheries Management 26:206-212

Roovers P, Baeten S, Hermy M (2004) Plant species variation across path ecotones in a variety of common vegetation types. Plant Ecology 170:107-119

Ros M, Garcia C, Hernandez T, Andrés M, Barja A (2004) Short-term effects of human trampling on vegetation and soil microbial activity. Communications in Soil Science and Plant Analysis 35:1591-1603

Scheffer M (1999) The effect of aquatic vegetation on turbidity: how important are the filter feeders? Hydrobiologia 408(409):307316

Scheuhammer AM, Norris SL (1995) A review of the environmental impacts of lead shotshell ammunition and lead fishing weights in Canada. Occasional Paper No. 88. Canadian Wildlife Service, Ottawa, Canada, 54 pp
Scheuhammer AM, Money SL, Kirk DA, Donaldson G (2003) Lead fishing sinkers and jigs in Canada: review of their use patterns and toxic impacts on wildlife. Occasional Paper No. 108. Canadian Wildlife Service, Ottawa, Canada, 48 pp

Schiemer F, Zalewski M, Thorpe JE (1995) Land/Inland water ecotones: intermediate habitats critical for conservation and management. Hypdrobiologia 303:259-264

Schindler DE, Scheuerell MD (2002) Habitat coupling in lake ecosystems. Oikos 98:177-189

Schramm HL, Edwards GB (1994) The perspectives on urban fisheries management: results of a workshop. Fisheries 19:9-15

Schramm HL, Gerard PD, Gill DA (2003) Importance of environmental quality and catch potential to fishing site selection by freshwater anglers in Mississippi. North American Journal of Fisheries Management 23:512-522

Slipke JW, Maceina MJ, Grizzle JM (1998) Analysis of the recreational fishery and angler attitudes towards hydrilla in Lake Seminole, a southwestern reservoir. Journal of Aquatic Plant Management 36:101-107

Snickars M, Sandström A, Mattila J (2004) Antipredator behaviour of 0 year Perca fluviatilis: effect of vegetation density and turbidity. Journal of Fish Biology 65:1604-1613

Stuart-Smith RD, Stuart-Smith JF, White RWG, Barmuta LA (2007) The impact of an introduced predator on a threatened galaxiid fish is reduced by the availability of complex habitats. Freshwater Biology 52:1555-1563

Sun D, Walsh D (1998) Review of studies on environmental impacts of recreation and tourism in Australia. Journal of Environmental Management 53:323-338

Suski CD, Cooke SJ (2007) Conservation of aquatic resources through the use of freshwater protected areas: opportunities and challenges. Biodiversity Conservation 16:2015-2029

Sutherland AR, Meyer JL (2008) Effects of increased suspended sediment on growth rate and gill condition of two southern Appalachian minnows. Environmental Biology of Fishes 80:389-403

Troutman JP, Rutherford DA, Kelso WE (2007) Patterns of habitat use among vegetation-dwelling littoral fishes in the Atchafalaya river basin, Louisiana. Transactions of the American Fisheries Society $136: 1063-1075$

United States Fish and Wildlife Service (2001) Fishing. Conserving the nature of America. Available at: http://www.fws.gov/fishing/ . Accessed 9 January 2008

Zar JH (1999) Biostatistical analysis, 4th edn. Prentice Hall, Upper Saddle River, NJ, pp 165-169 